\title{
History of Medicine.
}

TWO interesting lectures connected with the history of medicine were delivered at the Wellcome Medical Historical Museum at the end of last month by Sir William Willcox and Dr. A. P. Cawadias respectively. The former, who chose the subject of secret poisoning for his address, stated that the recent excavations in Mesopotamia have shown that an interest in poisons could be traced back to about 4500 в.c., when a goddess named Gula was worshipped by the Sumerians under the name of The Mistress of Charms and Spells and Controller of Noxious Poisons. The first scientific student of poisons, however, appears to have been Mithridates, king of Pontus, who not only conducted toxicological experiments on condemned criminals and others, but also wrote a book on the subject and invented a universal antidote which, according to Celsus, consisted of thirty-six ingredients. It is recorded that when he wished to commit suicide by poison, rather than surrender to the Roman invader, his constitution had become so inured to various poisons that his attempt was unsuccessful and he had to ask a mercenary to dispatch him with a sword. His name survives in modern scientific nomenclature, in the term 'mithridatism', which signifies immunity to poisons, bacterial and otherwise, acquired by gradually increasing doses of the poison itself.

During the Roman Empire, Agrippina and her son Nero made elaborate studies in experimental toxicology on the human subject, and by the knowledge thus obtained successfully removed the persons who incurred their disfavour. In the course of the next thousand years, poisoning was extensively practised without, however, any great developments taking place. in the science of toxicology, and it was not until the time of the Italian Renaissance that an intensive study of poisons was made, the most notorious experts in this field being Pope Alexander VI. and his son Cæsar Borgia.

Until modern times, the methods of detection of poisons depended mainly on the circumstances attending their administration. Nothing was really known about the post-mortem appearances, and toxicology did not make any great advance until the development of modern chemistry and its application to the analytical problems with which toxicology is concerned. While the only certain sign of poisoning is the identification by analysis of the poison in the body, of recent years so much progress has been made in morbid anatomy and histology that the post-mortem appearances often indicate the poison responsible for death apart from its detection in the body by chemical analysis. In conclusion, Sir William Willcox illustrated his address by the exhibition of curious poisons and their antidotes from the museum.

Dr. Cawadias, whose address was entitled "From Epidaurus to Galen: The Principal Currents of Greek Medical Thought", maintained that rational medicine was invented by the Greeks and that before their time the general attitude towards disease was irrational, medicine being essentially religious and magical in character. Although faith-healing was an important feature in the cult of Aisculapius at Epidaurus, it was limited to special cases of non-organic disease, and was free from the mystic element of the religious medicine of the ancient peoples of the East. Every period of ancient Greek medicine, of which five can be distinguished, is based on the physiological work of the ancient Ionian natural philosophers such as Thales and Anaximander.

In the first period, which included the seventh, sixth, and early fifth centuries B.C., a method of diagnosis based on physiological considerations with very elementary clinical control was elaborated together with rules for diet and gymnastics. In the second period, which included the fifth and fourth centuries B.c., Greek medicine became based on more precise physiological knowledge gained mainly by the researches of Anaxagoras of Clazomenæ, Democritus of Abdera, and Diogenes of Apollonia. The general mechanism of disease was explained more precisely by the doctrines of Hippocrates. Clinical medicine reached its zenith through the method of nosographical diagnosis developed by the Cnidians as well as by the method of personal diagnosis devised by Hippocrates and the school of Cos.

The doctrines of the third period, which included the last three centuries B.c. and the first two centuries A.D., were based on the physiological works of Aristotle and marked a very great advance in the knowledge of the functions of the various organs. This physiological work was supplemented by the Alexandrian physicians Herophilus and Erasistratus. Numerous medical schools flourished during this period. While the Alexandrians of the third century B.c. controlled research in physiology by a strict clinical examination, the Methodists and Pneumatists made physiology the sole basis of diagnosis and neglected the clinical method. The Empirics, on the other hand, confined themselves to clinical considerations and refused to consider any diagnostic method connected with the physiological mechanism of disease.

The fourth period of Greek medicine is represented by Galen alone (A.D. 130-200), whose physiological work marked an enormous advance on that of Aristotle owing to the introduction of the experimental method. The fifth and last phase of Greek medicine was a period of compilation and transmission, the principal compilers being Cælius Aurelianus (A.D. 400), Oribasius (A.D. 326-403), Alexander of Tralles (A.D. 525-605), and Paulus of Egina (A.D. 600-650). Their compilations were used by the Nestorian monks, who transmitted Greek medicine in the sixth and seventh centuries to the Arabians and through them in a slight degree to western Europe. The transmission of Greek medicine, however, was mainly due to the Greek scholars of the fifteenth century, who had left Greece after its conquest by the Turks.

\section{Cotton in Africa.}

THE report of the executive committee of the Empire Cotton Growing Corporation to the meeting of the administrative council, held in Manchester on Jan. 21 last, contains several important scientific observations on the growth of cotton in Africa.

The diseases and pests which attack the cotton plant are many, and each locality has its particular problems to solve in breeding resistant strains.
Cotton growing in South Africa has suffered from attacks by the jassid insect, and it is interesting to note that a strain has been isolated which is resistant to this pest. The new strain of cotton is giving high yields, which is of primary importance to the grower, and recent experience has shown that it is capable of giving good crops in districts with a seasonal rainfall of 10 inches, whereas it is generally considered that a minimum of 20 inches is necessary for cotton

No. 3147 , Vor. 125] 
growing. In Uganda, one of the most promising cotton-growing regions in South Africa, there are good prospects of increased yields, and steps are being taken to ensure this by instructing the native growers in improved methods of cultivation, and by effectively controlling the seed supply.

The cottons which the Corporation is cultivating in South Africa are of the American type, and are intended to provide the Empire with sources of supply other than America. It is to the Anglo-Egyptian Sudan that we have to look for the supply of the better quality cottons of the Egyptian type. The Sudan is now producing an increasing quantity of cotton which is almost indistinguishable from the best qualities of long staple Egyptian cotton. Re, cently the disease known as leaf curl has been attacking the crops in this locality, and there is evidence that the jassid insect is responsible for spreading the contagion. The Corporation is now considering the desirability of breeding jassid-resistant strains in the Sudan.

The Corporation, during the first years of its activities, found difficulty in obtaining agricultural scientific officers of adequate experience, but it is pleasing to note that it is now able to arrange for its senior officers to visit cotton-growing localities outside their own charge. Much good is expected of this interchange of thought and knowledge born of long experience, and the scheme should stimulate the younger officers who are striving to make headway in recently opened cotton-growing areas.

It is unfortunate that the continued depression in the cotton industry has made it necessary to reduce the spinners' levy from 3d. to $1 d$. per $500 \mathrm{lb}$. of raw cotton, but the Corporation will be able to carry out its full programme for the coming year by drawing on its accumulated reserves. The burden on the Corporation has been reduced in recent years by the increasing share that colonial governments ars now taking in the cost of developing cotton growing, and also because the Colonial Office is now training men for agricultural appointments on the lines initiated by the Corporation.

F. P. S.

\section{Meteorological Conditions accompanying a Waterspout.}

$\mathrm{A}^{\mathrm{T}}$

9.31 A.M., on June 14, 1929, a waterspout formed over Pensacola Bay, Florida, three hours after Lieut. P. G. Hale of the U.S. Navy had obtained accurate records of the pressure, temperature, and humidity of the atmosphere up to a height of 3000 metres close to the place where the spout developed. Mr. Hale also secured an admirable photograph of the phenomenon, taken from an aeroplane, which shows that the spout took the usual form of a sharply defined cord-like cloud stretching in a rather sinuous curve from the base of a cumulo-nimbus cloud to the sea, with a cloud of spray at its base.

At the time of the sounding, there was a dust horizon to the east at a height of about 2800 metres, and tall cumulus clouds were thrusting their heads through the haze top. Additional evidence of atmospheric instability was furnished by the graph of temperature and entropy plotted. on a Shaw "tephigram', which is reproduced together with the photograph in a short article in the Monthly Weather Review for August 1929. The article is of especial interest, owing to the attention directed to the subject by Wegener's recent introduction of the theory that the visible part of a waterspout is the extension of a whirl with a horizontal axis within the parent cumulonimbus cloud, and also because the chances are so against an aerial sounding happening to be made such a short time before the occurrence of a spout.

The 'tephigram' reveals an atmospheric environment such that a very moderate amount of general heating of the lower layers of the atmosphere, or, alternatively, a slight increase of their water-vapour near the surface, would allow any portion of the surface air with a little extra warmth or moisture to ascend automatically. It shows, further, that the ascending air would have possessed a large amount of surplus energy beyond that required merely for its ascent, such energy being available for developing the kinetic energy corresponding with the violent winds around the axis of a waterspout. This is the kind of information that a glance at the 'tephigram' will reveal to anyone familiar with it.

When we read that the construction of a 'tephigram' is a matter of daily routine for weather forecasting at the Pensacola air-station, it becomes clear that the thermodynamical researches of Carnot, Clausius, Maxwell, and others are beginning-mainly owing to Von Bezold in Germany and Napier Shaw in Great Britain-to have novel fields of practical application.

\section{University and Educational Intelligence.}

BIRMinghaM.- The annual meeting of the Court of Governors of the University is to be held on Feb.27, and the reports of the Vice-Chancellor and the Council, which are to be presented to the Court, have been issued. The Vice-Chancellor, Sir Charles Grant Robertson, reviews the changes which have occurred during the ten years of his tenure of office and is able to report much progress. The income and expenditure have greatly increased, and it is satisfactory to note that the largest item of expenditure is that of salaries. Nine members of the non-professorial staff have been promoted to Grade I. with a minimum salary of $£ 600$ a year-a reform long overdue. The number of students continues to increase slowly.

The eighth annual report of the Joint Standing Committee for Research shows an imposing array of subjects of research in aid of which grants have been made, and enumerates the publications of the various departments of the faculties of science, arts, medicine, commerce, and law. The report indicates a healthy activity in research over a wide range of subjects.

The event of the greatest moment to the University is the development of the new hospital scheme, in which an important step has been taken in the selection of plans for the buildings. If the money is forthcoming ( $f 1,000,000$ has been mentioned) a magnificent group of buildings will arise, on a site near to the University grounds, to accommodate the hospital and the University Medical School.

Cambridge.-Mr. W. R. Dean, of Trinity College, has been appointed University lecturer in mathematics.

LoNDon.-The Court of the University has gratefully accepted a bequest by the late Lady DurningLawrence of $£ 10,000$ for the equipment of the Physical and Electrical Chemistry Laboratory at University College.

Noтrce is given by the University of Wales that five fellowships, each of the annual value of $£ 200$ and tenable for two years, are to be awarded during the present year to graduates of the University. Applicacations for the fellowships should be sent by June I to the Registrar, University Registry, Cathays Park, Cardiff.

No. 3147, VoL. 125] 